\title{
Pattern of contraception among prior female users in a tertiary hospital in Northern Nigeria
}

\author{
Mohammed-Durosinlorun Amina*, Adze Joel, Bature Stephen, Abubakar Amina, Mohammed Caleb, Taingson Matthew and \\ Airede Lydia
}

${ }^{*}$ Correspondence: aminamhmd4@gmail.com

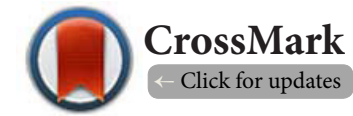

Department of Obstetrics and Gynaecology, Faculty of Clinical Sciences. College of Medicine. Kaduna State University, Kaduna, Nigeria.

\begin{abstract}
Experience with prior use of contraception may contribute to low uptake rates of modern contraceptives.

Objective: The objective of the study was to determine the pattern of current contraception among women with prior contraceptive use.

Methods: This was a retrospective study at a tertiary hospital in northern Nigeria. Available client records from the family planning clinic from January 1st, 2000 to March 31st, 2014 were retrieved. Information was collected on demographics, reproductive and contraceptive history. Data was analyzed using SPSS version 15 with significance level at $\mathrm{P}<0.05$.

Results: Majority of clients were aged $<35$ years (71.7\%); educated to secondary level (56.9\%); Muslims $(52.3 \%)$ and were spacing (76.2\%). Only $2621(43.8 \%)$ had used prior contraception and were more likely to be older, Christians, of higher parity, want no more children and use the intrauterine device (IUD) and implants for contraception $(p<0.05)$. The commonest type of prior contraception was injectables (45.2) and current contraception was IUD. About $42.1 \%$ continued their prior contraception. Age, religion, number of living children and reason for contraception were significantly associated with client's choice to continue prior contraception, or to switch to a new form of contraception $(\mathrm{p}<0.05)$, while educational status was not $(\mathrm{p}>0.05)$. On logistic regression, religion was the only significant variable in the model $(\mathrm{p}<0.05)$.

Concusion: The preferred form of current contraception among prior contraceptive users in our setting is the intrauterine device, and less Muslims are continuing with their prior choice.
\end{abstract}

Keywords: Contraception, prior contraception, female users, Northern Nigeria

\section{Introduction}

The maternal mortality ratio for Nigeria is 576 deaths per 100,000 live births which is quite alarming [1]. Effective contraception has proven to be a substantial and effective primary prevention strategy to reduce maternal mortality in developing countries $[2,3]$. According to the findings of the 2013 Nigeria Demographic and Health Survey (NDHS), knowledge of contraception is widespread in Nigeria; 85 percent of women and 95 percent of men report knowing about a contraceptive method [1]. Yet only fifteen percent of currently married women use a contraceptive method, an increase of only 2 percentage points from the 2003 NDHS [1]. Several reasons may account for the low uptake rates of modern contraception, including experience with prior use of contraception which is the focus of this study. Are there a lot of women with prior contraceptive use returning to the family planning clinics for repeat use? If so, are their choices the same or different from their previous choices? Repeat contraceptive use is unlikely to have been coerced. Those with prior use of contraception are likely to be more aware about contraceptive methods, including side effects, from previous counseling and previous use. Prior contraceptive experience may affect self-efficacy, the decision-making process for current or future contraceptive use and the next choice for contraceptive options $[4,5]$. Personal use and experience of contraception may lead to a satisfied or dissatisfied client. Perhaps satisfaction or dissatisfaction with a prior contraceptive method may influence 
Amina et al. Research Journal of Women's Health 2017,

future choices (continuation or discontinuation of a method) and affect overall uptake of contraception. Apart from discontinuation, dissatisfaction with a method of contraception can further lead to non-use, improper use or switching to a less reliable method of contraception [6-8].

A previous study done in Europe and South Africa showed that higher satisfaction rates among transdermal patch users were associated with higher adherence rates, compared to oral contraceptive $(\mathrm{OC})$ users, who experienced both lower satisfaction rates and lower adherence rates $[\mathbf{6 , 9}]$. The St. Louis Contraceptive CHOICE Project also showed that LARC (long acting reversible contraceptive) users exhibited both higher satisfaction ( $80 \%$ versus $54 \%$ ) and continuation rates (86\% vs. $55 \%$ ) compared to OC users $[6,7]$. In India, it was noted that continuing the use of injectable contraception was greater among women who experienced fewer side effects, received good quality of care and when the decision to adopt injectable contraceptives was made jointly by the woman and her husband [10]. Several Nigerian studies also report discontinuation of contraception due to side effects or a desire for more children [11-18].

While there are a lot of local and international studies on contraception in general, few have focused on prior contraceptive use. People who report contraceptive use need to be encouraged to maintain their behaviour, while those who do not, need to be motivated [19]. This study is important to document experience of contraception among prior female users, and because knowing the pattern of contraceptive choices following prior use is important to aid patient counselling, improve uptake and compliance, inform supply, and direct future contraceptive research and training of service providers.

\section{Materials and methods}

This was a retrospective study done at the Barau Dikko Teaching Hospital (BDTH), Kaduna, northern Nigeria. The hospital serves as a major referral facility for the metropolis and its environs. Approval for the study was gotten from the Kaduna State Ministry of Health. Client information was kept confidential. A family planning card is opened for all new clients to the facility. All available client records from the family planning clinic from January $1^{\text {st }}, 2000$ to March $31^{\text {st }}, 2014$ were retrieved without exclusion. Information was collected on demographics, reproductive, menstrual and contraceptive history, including prior use and contraceptive method chosen. Relevant data were analyzed using the statistical package for social sciences (SPSS) version 15. Missing responses were stated as such and excluded from analysis. Descriptive analysis was done using frequencies and percentages. Chi -square and logistic regression was used to test the association between prior and current use of contraception. Significance level was established at $P<0.05$.

\section{Results}

A total number of 5,992 client cards were retrieved and records indicate that all clients were female and married. Demographic characteristics are shown in Table 1. Majority of clients, $71.7 \%$, were aged $<35$ years while $28.3 \%$ were aged 35 years or above, with a mean age range of 30-34years. Majority of clients, $56.9 \%$ were educated up to, and completed their secondary education, while about $9.9 \%$ had received no form of formal education. There were more Muslim clients (52.3\%) than

Table 1. Socio-demographic and general characteristics of clients.

\begin{tabular}{|c|c|}
\hline Characteristic & Frequency (\%) \\
\hline $\begin{array}{l}\text { Age in years }(\boldsymbol{n}=5992) \\
<20 \\
20-24 \\
25-29 \\
30-34 \\
35-39 \\
40-44 \\
45-49 \\
\geq 50 \\
\text { Missing }\end{array}$ & $\begin{array}{l}131(2.2) \\
985(16.4) \\
1501(25.1) \\
1680(28.0) \\
1053(17.6) \\
455(7.6) \\
139(2.3) \\
47(0.8) \\
1(0.0)\end{array}$ \\
\hline $\begin{array}{l}\text { Education }(\boldsymbol{n}=5992) \\
\text { None } \\
\text { Some primary } \\
\text { Completed primary } \\
\text { Some secondary } \\
\text { Completed secondary or more } \\
\text { Missing }\end{array}$ & $\begin{array}{l}595(9.9) \\
409(6.8) \\
861(14.4) \\
685(11.4) \\
3410(56.9) \\
32(0.6)\end{array}$ \\
\hline $\begin{array}{l}\text { Religion }(\boldsymbol{n}=5992) \\
\text { Islam } \\
\text { Christianity } \\
\text { Others } \\
\text { Missing }\end{array}$ & $\begin{array}{l}3135(52.3) \\
2278(38.0) \\
33(0.6) \\
546(9.1)\end{array}$ \\
\hline $\begin{array}{l}\text { Number of children living }(\boldsymbol{n}=\mathbf{5 9 9 2}) \\
0 \\
1-2 \\
3-4 \\
>4 \\
\text { Missing }\end{array}$ & $\begin{array}{l}0(0) \\
1857(31.0) \\
1901(31.7) \\
2147(35.8) \\
87(1.5)\end{array}$ \\
\hline $\begin{array}{l}\text { Want more children? }(\boldsymbol{n}=5992) \\
\text { No } \\
\text { Yes } \\
\text { Unsure } \\
\text { Missing }\end{array}$ & $\begin{array}{l}624(10.4) \\
4565(76.2) \\
362(6.0) \\
441(7.4)\end{array}$ \\
\hline $\begin{array}{l}\text { Source of information }(\boldsymbol{n}=\mathbf{5 9 9 2}) \\
\text { Clinic personnel } \\
\text { Outreach personnel } \\
\text { Radio } \\
\text { Television } \\
\text { Print media } \\
\text { Friends/relatives } \\
\text { Another clinic } \\
\text { Community health worker } \\
\text { Others } \\
\text { Missing }\end{array}$ & $\begin{array}{l}3737(62.4) \\
53(0.9) \\
247(4.1) \\
177(3.0) \\
18(0.3) \\
1209(20.2) \\
14(0.2) \\
35(0.6) \\
6(0.1) \\
496(8.2)\end{array}$ \\
\hline $\begin{array}{l}\text { Chosen (current) contraception }(\boldsymbol{n}=\mathbf{5 9 9 2}) \\
\text { Oral contraceptive pills } \\
\text { Injectables } \\
\text { Implants } \\
\text { Intrauterine devices } \\
\text { Missing }\end{array}$ & $\begin{array}{l}673(11.2) \\
2423(40.4) \\
223(3.7) \\
2096(35.0) \\
577(9.7)\end{array}$ \\
\hline
\end{tabular}


Christians (38\%), while the others were missing or unspecified (9.7\%). There were no nulliparous clients recorded, while $31 \%$ had a parity of $1-2,31.7 \%$ had a parity of $3-4$ and $35.8 \%$ were grand multipara. The reason for contraception was for spacing in $76.2 \%$ of clients, while $10.4 \%$ of clients no longer wanted children. Clients received information about contraception from a variety of sources; most commonly from clinic personnel (62.4\%) and friends/relatives (20.2\%). The commonest form of contraception chosen by clients was "injectables" $(40.4 \%)$, followed by intrauterine devices (35\%), oral contraceptive pills (OCP)(11.2\%) and contraceptive implants (3.7\%). There were no records of barrier and permanent methods. Only $2621(43.8 \%)$ of the study population had used prior contraception. As shown in Table 2, prior contraceptive users

Table 2. Cross tabulation of socio-demographic/general factors and status of prior contraceptive use.

\begin{tabular}{|c|c|c|c|}
\hline \multirow[t]{2}{*}{ Characteristic } & \multicolumn{2}{|c|}{ Prior contraceptive use? } & \multirow[t]{2}{*}{ Statistical test } \\
\hline & & & \\
\hline \multicolumn{4}{|l|}{ Age in years $(n=5988)$} \\
\hline$<20$ & $124(94.7)$ & $7(5.3)$ & \multirow{9}{*}{$\begin{array}{l}X^{2}=598.434 \\
d f=7 \\
p=0.00\end{array}$} \\
\hline $20-24$ & $779(79.2)$ & $205(20.8)$ & \\
\hline $25-29$ & $871(58.0)$ & $630(42.0)$ & \\
\hline $30-34$ & $963(57.3)$ & $717(42.7)$ & \\
\hline $35-39$ & $456(43.3)$ & $598(56.7)$ & \\
\hline $40-44$ & $146(32.2)$ & $307(67.8)$ & \\
\hline $45-49$ & $24(17.3)$ & $115(82.7)$ & \\
\hline$\geq 50$ & $4(8.5)$ & $43(91.5)$ & \\
\hline Total & $3367(56.2)$ & $2621(43.8)$ & \\
\hline \multicolumn{4}{|l|}{ Education $(n=5957)$} \\
\hline None & $350(58.8)$ & $245(41.2)$ & \multirow{6}{*}{$\begin{array}{l}X^{2}=47.132 \\
d f=4 \\
p=0.00\end{array}$} \\
\hline Some primary & $247(60.4)$ & $162(39.6)$ & \\
\hline Completed primary & $560(65.1)$ & $300(34.9)$ & \\
\hline Some secondary & $343(50.1)$ & $342(49.9)$ & \\
\hline Completed secondary or more & $1855(54.4)$ & $1553(45.6)$ & \\
\hline Total & $3355(56.3)$ & $2602(43.7 \%)$ & \\
\hline \multicolumn{4}{|l|}{ Religion ( $n=5443$ ) } \\
\hline Islam & $1754(56.0)$ & $1378(44 / 0)$ & \multirow{4}{*}{$\begin{array}{l}X^{2}=36.381 \\
d f=2 \\
p=0.00\end{array}$} \\
\hline Christianity & $1097(48.2)$ & $1181(51.8)$ & \\
\hline Others & $23(69.7)$ & $10(30.3)$ & \\
\hline Total & $2874(52.8)$ & $2569(47.2)$ & \\
\hline \multicolumn{4}{|c|}{ Number of children living $(n=5902)$} \\
\hline $1-2$ & $1355(73.0)$ & $501(27.0)$ & \multirow{4}{*}{$\begin{array}{l}X^{2}=351.956 \\
d f=2 \\
p=0.00\end{array}$} \\
\hline $3-4$ & $984(51.8)$ & $915(48.2)$ & \\
\hline$>4$ & $949(44.2)$ & $1198(55.8)$ & \\
\hline Total & $3288(55.7)$ & $2614(44.3)$ & \\
\hline \multicolumn{4}{|l|}{ Want more children? $(n=5548)$} \\
\hline No & $176(28.3)$ & $446(71.7)$ & \multirow{4}{*}{$\begin{array}{l}X^{2}=254.212 \\
d f=2 \\
p=0.00\end{array}$} \\
\hline Yes & $2644(57.9)$ & $1920(42.1)$ & \\
\hline Unsure & $120(33.1)$ & $242(66.9)$ & \\
\hline Total & $2940(53.0)$ & $2608(47.0)$ & \\
\hline \multicolumn{4}{|l|}{ Source of information $(n=5493)$} \\
\hline Clinic personnel & $1973(52.8)$ & $1761(47.2)$ & \multirow{10}{*}{$\begin{array}{l}X^{2}=96.05 \\
d f=8 \\
p=0.00\end{array}$} \\
\hline Outreach personnel & $10(18.9)$ & $43(81.1)$ & \\
\hline Radio & $116(47.0)$ & $131(53.0)$ & \\
\hline Television & $87(49.2)$ & $90(50.8)$ & \\
\hline Print media & $18(100.0)$ & $0(0.0)$ & \\
\hline Friends/relatives & $618(51.1)$ & $591(48.9)$ & \\
\hline Another clinic & $14(100.0)$ & $0(0.0)$ & \\
\hline Community healthworker & $35(100.0)$ & $0(0.0)$ & \\
\hline Others & $0(0.0)$ & $6(0.0)$ & \\
\hline Total & $2871(52.3)$ & $2622(47.7)$ & \\
\hline \multicolumn{4}{|c|}{ Chosen (current) contraception $(n=5412)$} \\
\hline Oral contraceptive pills & $503(74.7)$ & $170(25.3)$ & \multirow{5}{*}{$\begin{array}{l}X^{2}=186.1 \\
d f=3 \\
p=0.00\end{array}$} \\
\hline Injectables & $1298(53.6)$ & $1122(46.6)$ & \\
\hline Implants & $101(45.3)$ & $122(54.7)$ & \\
\hline Intrauterine devices & $944(45.0)$ & $1152(55.0)$ & \\
\hline Total & $2846(52.6)$ & $2566(47.4)$ & \\
\hline
\end{tabular}

$\mathrm{n}=$ total number of clients analysed, $\mathrm{X}^{2}=$ chi square, $\mathrm{df}=$ degree of freedom, $\mathrm{p}=\mathrm{p}$ value (significance level) 
were more likely to be older, Christians, of higher parity, want no more children and to use the intrauterine device (IUD) and implants for contraception $(p<0.05)$. On the other hand, first time users were more likely to be younger, Muslims, of lower parity, want more children and use oral contraceptive pills and injectable for contraception ( $p<0.05)$. On cross tabulation the role of education and source of contraceptive information is less clear but still significantly different when prior contraceptive users are compared to new users $(p<0.05)$.

Among the subset of prior users, the commonest type of contraception used in the past was injectables (45.2\%), followed by IUD (26.7\%) and OCPs (25.5\%) while there were 65 missing responses (2.5\%) (Figure 1). Also among this subset of prior users, their current choice of contraception was most commonly IUD (43.9\%), then injectables (42.8), OCP (6.5\%), and implants (4.7\%) Figure 1 ).

Among the subset of prior users, 1103 clients (42.1\%) continued their prior method of contraception, 1414 (53.9\%) switched methods and there were 140 (4\%) missing responses. Table 3 shows that there was significant difference between the specific methods of past and current contraception among prior users $(\mathrm{P}<0.05)$. In majority of women that previously used OCPs, their preferred method for current contraception changed to injectable methods and only $9.1 \%$ continued using OCPs. More users of injectable contraception and IUDs still preferred to continue the same method for current contraception. Continuation rate for injectables was $50.2 \%$ and IUDs was $68 \%$.

As shown in Table 4, age, religion, number of living children and reason for contraception were significantly associated with client's choice to continue prior contraception or to switch to

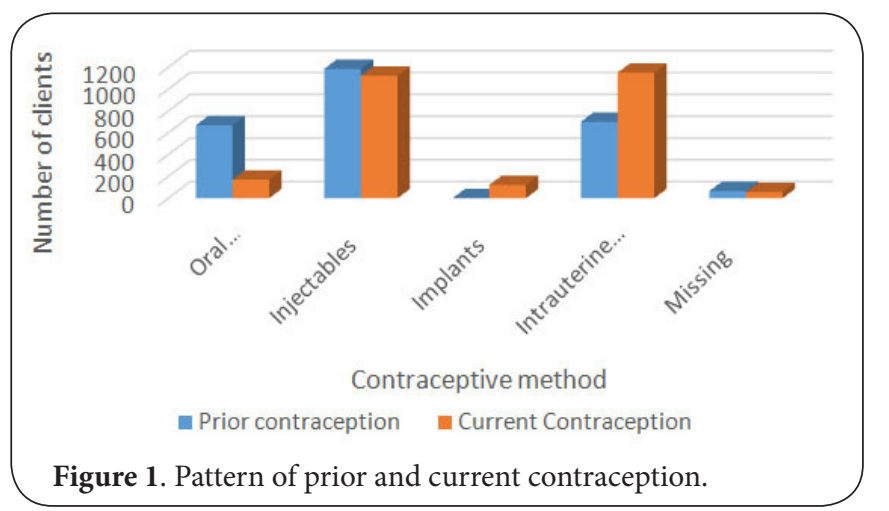

a new form of contraception $(p<0.05)$, while educational status was not ( $p>0.05$ ). Those aged $<35$ years were more likely to switch to other forms of contraception than those aged $>35$ years. Muslims were more likely to switch to other forms of contraception than Christians. Those of parity 1-4 were more likely to switch to other forms of contraception than those of parity $>4$. Those who wanted contraception for spacing were more likely to switch to other forms of contraception than thoselimiting their family size.

Logistic regression (Table 5) however shows that the odds of continuing with the same type of prior is 1.039 times higher for respondents with age less than 35 years than those with age greater than 35 years; 1.129 times higher with primary level or no education than those with secondary level or more education; is 0.456 less for Muslim respondents than the Christian respondents; and 0.841 times less for respondents with four or less children than those with more than four children. Overall however, religion was the only significant variable in the model $(p<0.05)$.

\section{Discussion}

It is interesting to note that all clients were married. Since there were no exclusions, perhaps there was inadequate privacy and clients do not disclose their status for fear of stigma, especially in a more conservative setting of northern Nigeria. Other studies agree that in Nigeria, family planning clinics may not be adolescent-friendly, especially for unmarried adolescents, since it is regarded as the exclusive preserve of the married $[17,18]$. Also, record keeping for barrier and permanent methods of contraception was poor, especially as they were sometimes provided by other departments of the hospital and so was not captured in our data.

In our study, $43.8 \%$ of the study population had used prior contraception. Not too many studies have specifically looked at prior contraceptive use, so it is difficult to make comparison to our study. In one study done in llorin (Nigeria), 5,563 of 10,002 (55.6\%) family planning clients had used contraception in the past [20]. In Jos 82\% of 1401 women that accepted Jadelle contraceptive implants had previously used other contraceptives (mostly short-acting methods such as injectables, pills, and condoms) [18].

Prior contraceptive users presenting to our clinic were more likely to be older, Christians, of higher parity, and want no more children. The reasons for this may not be far-fetched.

Table 3. Comparison of prior and current choice of contraception used by the subset of prior contraceptive users.

\begin{tabular}{llllll}
\hline Prior contraception & Current chosen contraception & & \\
\hline & OCPs & Injectables & Implants & IUDs & Row Total (\%) \\
Oral contraceptive pills (OCPs) & $61(9.1 \%)$ & $383(57.2 \%)$ & $8(1.2 \%)$ & $217(32.4 \%)$ & $669(100 \%)$ \\
Injectables & $43(3.7 \%)$ & $578(50.2 \%)$ & $96(8.3 \%)$ & $434(37.7 \%)$ & $1151(100 \%)$ \\
Intrauterine devices (IUDs) & $55(7.9 \%)$ & $150(21.5 \%)$ & $18(2.6 \%)$ & $474(68.0 \%)$ & $697(100 \%)$ \\
\hline
\end{tabular}

Number of respondents=2517; Pearson Chi square $=314.214$; Degree of freedom $=6$; P value $=0.000$ 
Table 4. Cross tabulation of several factors and status of continuing prior contraception or not.

\begin{tabular}{|c|c|c|}
\hline \multirow[t]{2}{*}{ Variable } & \multicolumn{2}{|c|}{ Continuing contraceptive method? } \\
\hline & $\begin{array}{l}\text { Yes } \\
\text { (row \%) }\end{array}$ & $\begin{array}{l}\text { No } \\
\text { (row \%) }\end{array}$ \\
\hline $\begin{array}{l}\text { Age }(n=2516) \\
<35 \text { years } \\
>35 \text { years } \\
\text { Likelihood ratio }=\mathbf{3 4 . 2 8 5} ; \mathbf{d f}=\mathbf{4} ; \mathbf{p}=\mathbf{0 . 0 0 0}\end{array}$ & $\begin{array}{l}646(42.4) \\
456(45.9)\end{array}$ & $\begin{array}{l}878(57.6) \\
536(54.1)\end{array}$ \\
\hline $\begin{array}{l}\text { Education }(\mathrm{n}=\mathbf{2 4 9 7}) \\
\text { Primary or none } \\
\text { Secondary or more } \\
\text { Pearson Chi Square }=\mathbf{4 . 5 7 1} ; \mathbf{d f}=\mathbf{4} ; \mathbf{p}=\mathbf{0 . 3 3 4}\end{array}$ & $\begin{array}{l}315(46.1) \\
778(42.9)\end{array}$ & $\begin{array}{l}369(53.9) \\
1035(57.1)\end{array}$ \\
\hline $\begin{array}{l}\text { Religion }(\mathrm{n}=\mathbf{2 4 5 4}) \\
\text { Islam } \\
\text { Christianity } \\
\text { Pearson Chi Square=95.106; } \mathrm{df}=\mathbf{4} ; \mathrm{p}=\mathbf{0 . 0 0}\end{array}$ & $\begin{array}{l}470(35.2) \\
595(53.2)\end{array}$ & $\begin{array}{l}864(64.7) \\
525(46.8)\end{array}$ \\
\hline $\begin{array}{l}\text { Living children }(\mathrm{n}=\mathbf{2 5 0 9}) \\
1-4 \\
\geq 5 \\
\text { Likelihood ratio=42.163; } \mathrm{df}=4 ; \mathrm{p}=\mathbf{0 . 0 0 0}\end{array}$ & $\begin{array}{l}572(42.9) \\
531(45.1)\end{array}$ & $\begin{array}{l}761(57.1) \\
645(54.9)\end{array}$ \\
\hline $\begin{array}{l}\text { Want more children? }(\mathbf{n}=\mathbf{2 3 1 5}) \\
\text { No (limiters) } \\
\text { Yes (spacers) } \\
\text { Pearson Chi Square=219.424; } \mathbf{d f}=\mathbf{4} ; \mathbf{p}=\mathbf{0 . 0 0}\end{array}$ & $\begin{array}{l}198(45.5) \\
822(43.7)\end{array}$ & $\begin{array}{l}237(54.5) \\
1058(56.3)\end{array}$ \\
\hline
\end{tabular}

$\mathrm{n}=$ number analysed, $\mathrm{df}=$ degree of freedom, $\mathrm{p}=$ significant value

Table 5. logistic regression of several factors and status of continuing prior contraception or not.

\begin{tabular}{|c|c|c|c|c|c|}
\hline \multirow[t]{2}{*}{ Variables } & \multicolumn{5}{|c|}{ Status of contraception } \\
\hline & Same (\%) & Switch(\%) & OR (crude) & $95 \% \mathrm{CI}$ & $P$ \\
\hline \multicolumn{6}{|l|}{ Age (Years) } \\
\hline$<35$ & $646(42 \%)$ & $878(58 \%)$ & 1.039 & $0.871-1.241$ & 0.669 \\
\hline$>35$ & $456(46 \%)$ & $536(54 \%)$ & -- & -- & -- \\
\hline \multicolumn{6}{|l|}{ Religion } \\
\hline Christianity & $595(53 \%)$ & $525(47 \%)$ & .456 & $0.384-0.542$ & 0.000 \\
\hline Islam & $470(35 \%)$ & $864(65 \%)$ & -- & -- & -- \\
\hline \multicolumn{6}{|l|}{ Level of Education } \\
\hline Primary or none & $315(46 \%)$ & $369(54 \%)$ & 1.129 & $0.941-1.396$ & 0.261 \\
\hline Secondary or more & $778(43 \%)$ & $1035(57 \%)$ & -- & -- & -- \\
\hline \multicolumn{6}{|l|}{ No of Children } \\
\hline $1-4$ & $572(43 \%)$ & $716(57 \%)$ & .841 & $0.694-1.020$ & 0.079 \\
\hline$>4$ & $531(45 \%)$ & $645(55 \%)$ & -- & -- & -- \\
\hline
\end{tabular}

Older women may have been exposed to coitus longer and have a higher and continuing need for contraception. Also, women of higher parity and wanting to limit their family size may be more motivated to seek out contraceptive services. Indeed, couples and women who desire more children are less likely to use contraception [21]. Other studies also show an inverse relationship between number of living children and use of contraception [22,23]. The findings that Muslim women in the northeast and northwest of the country are less likely to have an unmet need to limit fertility are consistent with the higher fertility levels found in those regions [24].
Among prior contraceptive users, the commonest type of contraception used in the past was injectables (45.2\%). This is in keeping with national Nigerian statistics; injectables are the commonest form of modern contraceptives used by Nigerian women (3\%), followed by condoms and pills (2\%) [1]. Injectables being the commonest type of contraception used in Nigeria is similar to what was found in other studies [12-15], but contrasts with the findings from Jos, north-central Nigeria where IUD was the commonest [25]. Injectable methods may be popular because they offer contraception that is effective, reversible, does not 
Amina et al. Research Journal of Women's Health 2017,

http://www.hoajonline.com/journals/pdf/2054-9865-4-4.pdf

doi: 10.7243/2054-9865-4-4

require daily use, and can be concealed from spouses [26]. In our study, implants did not feature as a method of prior contraception probably because of the timing of introduction of the product to the center. Hence, choice of contraception also depends on the supply of commodities, type of counseling received and provider bias. Nigeria has a narrow scope of contraceptive methods available in the country in comparison to developed countries, and is constantly trying to expand this. With economic recession and low spending on health, it might be more cost effective to tailor contraceptive supply to patient's preferences. Women, no matter where they live, should have access to lifesaving contraceptives [27]. Uniform distribution of available contraceptives across all parts of the country is thus important since implants had been introduced to the country as early as 1985 [28].

Our study showed that there were significant differences between the specific methods of past and current contraception among prior users. The commonest choice for current contraception among prior users in our study was IUD rather than injectables. The IUD is very popular and is widely used in Nigeria, particularly by older married women [11]. Worldwide and in low income countries, there is a growing trend towards increased use of long acting reversible contraception (LARC) which includes the IUD [29]. Apart from its longer action, the IUD is also effective and has more satisfaction and less discontinuation rates. In this study, $68 \%$ of prior IUD users chose to continue with IUD. This may imply high satisfaction rates. But a study in Jos showed $46.3 \%$ of clients discontinued IUD within 3 years with the highest rate at 1 year (24.2\%), commonly due to a desire for pregnancy (50.9\%), excessive menstrual bleeding (10.4\%), vaginal discharge PID (9.0\%), and other reasons [30].

Among prior OCP users in this study, $19 \%$ chose to continue $\mathrm{OCP}$, which is quite low. Oral contraceptive use is however generally characterized by relatively high discontinuation rates and low adherence to treatment due to the shorter action and daily dosing regimen [31]. According to the Nigerian Health and Demographic Survey contraceptive discontinuation rate is $28 \%$ within a year, and it is highest for pills and injectables (26\% and 23\%), while for IUD it is $9.1 \%$ [1]. In one Swedish study, the most prescribed and dispensed hormonal contraceptives during the study period were combined oral contraceptive pills (COC) and the type prescribed affected continuation/discontinuation rates. Women who received an initial prescription of ethinylestradiol combined with either levonorgestrel or drospirenone were more prone to continue with the same drug, while women who received desogestrelonly had a $35 \%$ higher probability to choose another type of contraceptive within 6 months of use [32].

Among prior injectable users in this study, $50.2 \%$ choose to continue with injectables. Some studies in Africa and the Philippines found that some of the discontinuers of injectable contraception were "taking a break" mainly due to abnormal bleeding patterns and intended to return for another injec- tion when their normal menstrual cycle returned $[33,34]$ Unfortunately, this results in improper use of contraception which may lead unintended pregnancies $[33,34]$. Following discontinuation of injectable contraceptive use in India, about three in ten women switched immediately to another contraceptive method [10]. Some health care providers also noted that method switching was common among women who discontinued using injectable contraceptives for methodrelated reasons, and that the two methods to which women most commonly switched were tubal ligation and the IUD [10].

Religion was a significant factor determining if prior users chose the same method or switched to another form of contraception. Muslims were more likely to switch to other forms of contraception than Christians in our study. It is important to note that some level of method-related discontinuation is to be expected if a woman starts using a method and then finds that it is not suitable for her needs or preferences [27]. Abnormal bleeding patterns are common side effects of most forms of contraception and can disrupt worship for Muslims [26]. and may account for why they switch methods in search for a more suitable one.

This study is however limited by its retrospective, quantitative design and was hospital based. Deeper understanding of experiences with prior contraception, reasons for continuation and discontinuation of a specific method of contraception would be better using qualitative or mixed methods. Generalization of findings to the community is limited as a community study can better detect women with prior contraceptive use that do not come to the hospital.

\section{Conclusions}

The preferred form of current contraception among women with prior contraceptive use in our setting was the intrauterine device and this should be taken into consideration when counselling and supplying contraceptives. Overall, when comparing prior and current contraceptive use among clients, there is a move towards longer acting contraceptives (injectable to IUD), though national contraceptive uptake is still low. Less Muslims were continuing their prior form of contraception. The range of contraceptive commodities needs to be expanded and evenly distributed country wide to improve access to effective contraception and reduce unmet needs from method discontinuation. Counselling should be improved for women to cope with side effects. Further qualitative studies are however, needed to further elucidate findings. Family planning clinic and providers in Northern Nigeria should ensure adequate privacy and positive attitudes for their clients so that contraceptive needs of single but sexually active females, single parents, widows or divorcees can be met. Quality of record keeping also needs to improve.

\section{Competing interests}

The authors declare that they have no competing interests. 
Amina et al. Research Journal of Women's Health 2017,

Authors' contributions

\begin{tabular}{|l|c|c|c|c|c|c|c|}
\hline Authors' contributions & MDA & AJ & BS & AA & MC & TM & AL \\
\hline Research concept and design & $\checkmark$ & -- & -- & -- & -- & -- & -- \\
\hline Collection and/or assembly of data & $\checkmark$ & $\checkmark$ & $\checkmark$ & $\checkmark$ & $\checkmark$ & $\checkmark$ & $\checkmark$ \\
\hline Data analysis and interpretation & $\checkmark$ & -- & -- & -- & -- & -- & -- \\
\hline Writing the article & $\checkmark$ & -- & -- & -- & -- & -- & -- \\
\hline Critical revision of the article & $\checkmark$ & $\checkmark$ & $\checkmark$ & $\checkmark$ & $\checkmark$ & $\checkmark$ & $\checkmark$ \\
\hline Final approval of article & $\checkmark$ & $\checkmark$ & $\checkmark$ & $\checkmark$ & $\checkmark$ & $\checkmark$ & $\checkmark$ \\
\hline Statistical analysis & $\checkmark$ & -- & -- & -- & -- & -- & -- \\
\hline
\end{tabular}

Publication history

EIC: Erich Cosmi, University of Padua, Italy.

Received: 20-Jun-2017 Final Revised: 01-Aug-2017

Accepted: 25-Aug-2017 Published: 03-Sep-2017

\section{References}

1. National Population Commission [Nigeria] and ICF International. Nigeria Demographic and Health Survey 2013. Abuja, Nigeria, Rockville, Maryland, USA. 2014.

2. Kana MA, Tagurum YO, Hassan Zl, Afolanranmi TO, Ogbeyi GO, Difa $J A$, Amede $P$ and Chirdan OO. Prevalence and determinants of contraceptive use in rural Northeastern Nigeria: Results of a mixed qualitative and quantitative assessment. Annals Nigerian Medicine. 2016; 10:3-10. | Article

3. Ahmed S, Li Q, Liu L and Tsui AO. Maternal deaths averted by contraceptive use: an analysis of 172 countries. Lancet. 2012; 380:11125. | Article | PubMed

4. Sucato GS, Bhatt SK, Murray PJ and Ott MA. Transdermal contraception as a model for adolescent use of new methods. J Adolesc Health. 2011; 49:357-62. | Article | PubMed

5. Wang RH, Wang HH, Cheng CP, Hsu HY and Lin SY. Testing a model of contraception use behavior among sexually active female adolescents in Taiwan. Res Nurs Health. 2007; 30:628-40. | Article | PubMed

6. He K, Dalton VK, Zochowski MK and Hall KS. Women's Contraceptive Preference-Use Mismatch. J Womens Health (Larchmt). 2017; 26:692701. | Article | PubMed

7. Peipert JF, Zhao Q, Allsworth JE, Petrosky E, Madden T, Eisenberg D and Secura $G$. Continuation and satisfaction of reversible contraception. Obstet Gynecol. 2011; 117:1105-13. | Article | PubMed Abstract | PubMed FullText

8. Moreau C, Cleland $\mathrm{K}$ and Trussell J. Contraceptive discontinuation attributed to method dissatisfaction in the United States. Contraception. 2007; 76:267-72. | Article | PubMed

9. Urdl W, Apter D, Alperstein A, Koll P, Schonian S, Bringer J, Fisher AC and Preik M. Contraceptive efficacy, compliance and beyond: factors related to satisfaction with once-weekly transdermal compared with oral contraception. Eur J Obstet Gynecol Reprod Biol. 2005; 121:202-10. | Article | PubMed

10. Jejeebhoy SJ and Francis-Zavier AJ. Injectable contraceptives: Perspectives and experiences of women and health care providers in India. New Delhi: Population Council. 2012. | Article

11. Monjok E, Smesny A, Ekabua JE and Essien J. Contraceptive practices in Nigeria: Literature review and recommendation for future policy decisions. Open Access Journal of Contraception. 2010; 1:9-22.

12. Muhammad $Z$ and Maimuna DG. Contraceptive trend in a tertiary facility in North Western Nigeria: A 10-year review. Nigerian Journal of Basic and Clinical Sciences. 2014; 11:99-103. | Article

13. Awusi VO. Contraceptive choice amongst women in Warri, Nigeria. International Journal of life sciences and Pharmacological Research. 2012; 2:35-39.

14. Ojiyi E and Dike El. The choice of contraceptives among women in Orlu, Nigeria. Porthacourt Medical Journal. 2009; 4:63-7. | Article

15. Ameh $\mathrm{N}$ and Sule ST. Contraceptive choices among women in Zaria, Nigeria. Niger J Clin Pract. 2007; 10:205-7. | PubMed

16. Mutihir JT and Pam VC. Overview of contraceptive use in Jos University Teaching Hospital, north central Nigeria. Niger J Clin Pract. 2008; 11:139-
43. I PubMed

17. Eke $A C$ and Alabi-Isama L. Long-acting reversible contraception (LARC) use among adolescent females in secondary institutions in Nnewi, Nigeria. J Obstet Gynaecol. 2011; 31:164-8. | Article | PubMed

18. Pam VC, Mutihir JT, Nyango DD, Shambe I, Egbodo CO and Karshima JA. Sociodemographic profiles and use-dynamics of Jadelle (levonorgestrel) implants in Jos, Nigeria. Niger Med J. 2016; 57:314-319. | Article | PubMed Abstract | PubMed FullText

19. Campo S, Askelson NM, Spies EL and Losch M. Ambivalence, communication and past use: understanding what influences women's intentions to use contraceptives. Psychol Health Med. 2012; 17:356-65. | Article | PubMed

20. Ajiboye A, Adesina KT, Abdul IF and Ezeoke GG. Patterns of contraceptive usage at family planning clinics in Ilorin, Nigeria. Bangladesh Medical Journal. 2015; 44:140-145.

21. Ejembi $C L$, Tukur $D$ and Aliyu $A$. Contextual factors influencing modern contraceptive use in Nigeria. DHS working papers No 120. Rockville, Maryland, USA: ICF International. 2015.

22. Mahmood N and Ringheim K. Knowledge, approval and communication about family planningas correlates of desired fertility among spouses in Pakistan. International Family Planning Perspectives. 1999; 23:122-129.

23. Lakew $Y$, Reda AA, Tamene H, Benedict $S$ and Deribe K. Geographical variation and factors influencing modern contraceptive use among married women in Ethiopia: evidence from a national population based survey. Reprod Health. 2013; 10:52. | Article | PubMed Abstract | PubMed FullText

24. Austin A. Unmet contraceptive need among married Nigerian women: an examination of trends and drivers. Contraception. 2015; 91:31-8. | Article | PubMed

25. Mutihir JT and Pam VC. Overview of contraceptive use in Jos University Teaching Hospital, north central Nigeria. Niger J Clin Pract. 2008; 11:13943. | PubMed

26. Mohammed-Durosinlorun, A, Abubakar A, Adze J, Bature S, Mohammed C, Taingson, $\mathrm{M}$ and Ojabo A. Comparison of Contraceptive Methods Chosen by Breastfeeding, and Non-Breastfeeding, Women at a Family Planning Clinic in Northern Nigeria. Health. 2016; 8:191-197. | Article

27. Castle $S$ and Askew I. Contraceptive discontinuation: reasons, challenges and solutions. Family planning 2020 (FP 2020). Population Council. 2015.

28. Ladipo OA and Akinso SA. Contraceptive implants. Afr J Reprod Health. 2005; 9:16-23. | PubMed

29. Staveteig S, Mallick L and Winter R. Uptake and Discontinuation of LongActing Reversible Contraceptives (LARCs) in Low-Income Countries. DHS Analytical Studies No. 54. Rockville, Maryland, USA: ICF International. 2015. I Article

30. Anyaka C, Ocheke A, Shambe I, Kahansim M, Oyebode T, Pam V and Ekwempu C. Discontinuation Pattern Among Intrauterine Contraceptive Device Users at Jos University Teaching Hospital, Jos, Nigeria. Journal of Gynecology and Obstetrics. 2016; 4:53-56.

31. Trussell J. Understanding contraceptive failure. Best Pract Res Clin Obstet Gynaecol. 2009; 23:199-209. | Article | PubMed Abstract | PubMed FullText

32. Josefsson $A$, Wirehn AB, Lindberg M, Foldemo A and Brynhildsen J. Continuation rates of oral hormonal contraceptives in a cohort of firsttime users: a population-based registry study, Sweden 2005-2010. BMJ Open. 2013; 3:e003401. | Article | PubMed Abstract | PubMed FullText

33. Beksinska ME, Rees HV and Smit J. Temporary discontinuation: a compliance issue in injectable users. Contraception. 2001; 64:309-13. I Article I PubMed

34. Henry R. Contraceptive practice in Quirino Province, Philippines: experiences of side effects. University of the Philippines Population Institute, University of La Salette, and Macro International Inc.: Calverton, Maryland. 2001.

\section{Citation:}

Amina M-D, Joel A, Stephen B, Amina A, Caleb M, Matthew T and Lydia A. Pattern of contraception among prior female users in a tertiary hospital in Northern

Nigeria. Res J Womens Health. 2017; 4:4. http://dx.doi.org/10.7243/2054-9865-4-4 